\title{
SEASONAL SURFACE DRAINAGE OF SLOPING FARMLAND: A REVIEW OF ITS HYDROGEOMORPHIC IMPACTS
}

\author{
Elise Monsieurs ${ }^{1}$, Mekete Dessie ${ }^{2,3}$, Enyew Adgo ${ }^{4}$, Jean Poesen ${ }^{5}$, Jozef Deckers ${ }^{5}$, Niko Verhoest ${ }^{3}$, Jan Nyssen ${ }^{1 *}$ \\ ${ }^{1}$ Department of Geography, Ghent University, Gent, Belgium \\ ${ }^{2}$ School of Civil and Water Resources Engineering, Bahir Dar University, Bahir Dar, Ethiopia \\ ${ }^{3}$ Laboratory of Hydrology and Water Management, Ghent University, Ghent, Belgium \\ ${ }^{4}$ Department of Natural Resources, Bahir Dar University, Bahir Dar, Ethiopia \\ ${ }^{5}$ Department of Earth and Environmental Sciences, KU Leuven, Leuven, Belgium
}

Received: 26 November 2013; Revised: 2 March 2014; Accepted: 3 March 2014

\begin{abstract}
The combination of runoff-generating areas (saturated soils) and overland flow concentration in features such as drainage ditches makes sloping farmland vulnerable to soil erosion. The establishment of drainage ditches aims at draining the excess of water from the farmland, particularly in areas where soils are saturated in the rainy season. The hydrogeomorphic impacts on the farmland itself and on downstream areas need however also to be studied. Off site, downstream problems comprise higher peak discharges, leading to gully initiation, an increase in sediment load, and flooding problems. On-site problems such as the development of the drainage ditches into (ephemeral) gullies are less documented, although they may be important, as illustrated in the Lake Tana Basin (Ethiopia). The similarities and interactions between ephemeral gully channels and drainage ditches have to be considered to better understand all effects of drainage. Drainage ditches are a potential source of conflict between farmers with different interests and power, as well as between upstream and downstream users. A case study on drainage ditches on sloping farmlands in the Lake Tana Basin showed that nine out of ten catchments had drainage densities by ditches ranging from 53 to $510 \mathrm{~m} \mathrm{ha}^{-1}$. Drainage ditches were constructed with an average top width of 27 $( \pm 9) \mathrm{cm}$. A significant correlation was found between stone bund density (physical conservation structures) and ditch drainage density $(R=-0 \cdot 72)$, in line with the Ethiopian government's ban on drainage ditches in farmlands where stone bunds have been constructed. Copyright (C) 2014 John Wiley \& Sons, Ltd.
\end{abstract}

KEYWORDS: drainage ditch; cut-off drain; runoff; ephemeral gully; soil saturation; rill; stone bund

\section{INTRODUCTION}

As population densities are rising, more pressure is put on the land, and even steep sloping areas are cultivated (Turkelboom et al., 2008; Smit \& Tefera, 2011; Mekuria et al., 2012; Haile \& Fetene, 2012). In regions where soils have poor internal drainage and where rainfall depth exceeds evapotranspiration depth during the rainy season, nearly all sloping farmlands require drainage for crop production. Although drainage has a wide range of benefits, in many cases, the establishment of drainage ditches is perceived as a major mismanagement of farmland that leads to on-site and off-site land degradation (Smit \& Tefera, 2011; Simane et al., 2013; Zhang et al., 2013). The environmental impacts of land surface drainage cannot be simply and clearly stated: For instance, Pathak et al. (2005) and Turkelboom et al. (2008) report that drainage ditches on steep slopes can control gully erosion by diverting the water away from the gully head, whereas other studies point to drainage ditches as triggers of gullies (Archibold et al., 2003; Ireland et al., 1939; Smit \& Tefera, 2011; Zhang et al. 2013). Because gully erosion is the worst stage of soil erosion by water

*Correspondence to: J. Nyssen, Department of Geography, Ghent University, Krijgslaan 281 S8, B-9000 Gent, Belgium.

E-mail: jan.nyssen@ugent.be and a worldwide problem (Poesen et al., 2003; Valentin et al., 2005), a comprehensive analysis on the hydrological effects of man-made drainage ditches is required.

Here, we review the effects of drainage ditches on sloping farmland with a focus on drainage ditch systems as a factor initiating rill and gully erosion. First, we consider seasonal soil saturation as a trigger for runoff production (Archibold et al., 2003). As overland flow leads to soil erosion on farmlands and loss of crop yield (Tilahun et al., 2013; Ngatcha et al., 2011; Singh \& Agnihotri, 1987), the use of drainage ditches and their positive effects for crop production are introduced in the next section. Next, the negative effects of enhanced drainage are presented at different scales. Off-site effects such as gully formation (Burkard \& Kostachuk, 1995; Turkelboom et al., 2008) and increased peak discharge (Holden et al., 2004; Skaggs et al., 1994) are taken into account, followed by the on-site effects (Tebebu et al., 2010; Shiferaw, 2002). Besides these drainage ditches, we discuss thereafter the naturally formed ephemeral gullies (EGs) that show some similarities with human-made drainage ditches (Bewket \& Sterk, 2003; Zhang et al., 2007) and consider the spatial and social dimensions of these effects of drainage ditches. We finish with a brief example of the use of drainage ditches in the Lake Tana Basin (Ethiopia) to illustrate the need for further research on the hydrogeomorphic effects of drainage ditches. 


\section{METHODS}

A critical examination was carried out of 62 scientific (peerreviewed) journal articles, $3 \mathrm{MSc}$ theses, and 13 other publications (governmental reports, Food and Agriculture Organization reports, conference proceedings, and chapters in books). This review is illustrated through participatory observations on drainage ditches in the Lake Tana Basin in Ethiopia, including fieldwork during summer 2013, which consisted of interviewing different stakeholders concerning drainage ditches (government officials, farmers, and scientists at the Bahir Dar University), measuring drainage ditch characteristics (top width of drainage ditches and drainage density), and other explanatory factors such as stoniness, soil depth, and average slope gradient.

\section{SEASONAL SOIL SATURATION AND RUNOFF}

The occurrence of surface runoff has been schematically illustrated by Steenhuis et al. (2009) and Bayabil et al. (2010) who divide basins in the hill slopes and the lower, relatively flatter areas. Precipitation on the hill slopes can partly infiltrate and partly flow downslope as (sub) surface flow. Areas in the landscape where run-on and rain depth are greater than runoff and infiltration become saturated during the rainy season. The differences in flow discharge along the slope are due to differences in slope gradient, concavity of the area, depth to an impermeable layer in the soil (Bayabil et al., 2010), transmissivity (James \& Roulet, 2009), and rainfall characteristics (Ziadat \& Taimeh, 2013).

Saturation of the soil and jointly its effect on surface runoff is often seasonally bound. Tilahun et al. (2013), Ngatcha et al. (2011), and Singh \& Agnihotri (1987) amongst others studied the erosive effects of overland flow due to soil saturation during the rainy season in Ethiopia, Cameroon, and India, respectively. Concentrated overland flow is the main factor of gully erosion on cropland (Govers et al., 1990; Auzet et al., 1993). Because of soil saturation, more runoff water is produced that is captured by the drainage ditch system. Higher discharges lead to a larger erosive force of the flows in the downstream gullies (Archibold et al., 2003). Shallow soils, if occurring in the middle and lower parts of the slopes, get saturated more quickly, and hence, rill and gully initiation is more likely in these areas (Zhang et al., 2007; Steenhuis et al., 2009; Bewket \& Sterk, 2003).

\section{DRAINAGE OF SLOPING FARMLAND}

The aim of digging drainage ditches on cropland is to reduce the negative effects of excess of water on crops. The primary objective of a drainage system on sloping land is to capture the temporary excess of water and evacuate it downhill. Artificial drainage of the land aims at securing an unsaturated top soil layer and attains the following: (i) reduces the damage from scalding due to the detrimental effect of ponding water in hot areas (Luthin, 1966); (ii) prevents soil compaction as a result of animal trampling on saturated soil; (iii) supports crop germination as drained soils are warmer; (iv) prevents subsurface anoxic conditions (waterlogging); (v) enhances the water holding capacity; (vi) increases aeration; (vii) leads to more uniform crop growth; (viii) allows a greater variety of crops; (ix) leads to a deeper root zone; (x) protects plants from disease; and (xi) decreases the mechanical power needed for tillage operations (Luthin, 1966; Robinson, 1990; Spaling and Smit, 1995; Zhang et al., 2013).

In contrast to level areas where drainage ditches mainly aim at lowering the level of the phreatic surface when it comes near or at the surface (Schot et al., 2004; Qureshi et al., 2013), digging ditches to divert runoff water on sloping cropland is a physical soil conservation practice to protect the land from uncontrolled runoff and hence decrease the risk of topsoil and seedling erosion. It is also used to control gully erosion by diverting runoff water away from active gully heads (Pathak et al., 2005; Shiferaw, 2002). Such structures that intercept overland flow and divert it laterally to a supposedly safe and well-established drainage channel are called cut-off drain, diversion ditch (Turkelboom et al., 2008), slanted drain, or locally in Ethiopia, tekebekeb (Shiferaw, 2002) or feses.

In the Roujan Basin in France, drainage ditches are 0.7$1.2 \mathrm{~m}$ wide and 0.8-1.4 $\mathrm{m}$ deep (Moussa et al., 2002). Million (1996) found in his study in North Shewa highlands in Ethiopia drainage ditches of which the width varied from 30 to $50 \mathrm{~cm}$ and depth from 5 to $25 \mathrm{~cm}$. In northern Thailand and Ethiopia, Turkelboom et al. (2008) and Shiferaw (2002) concluded that the widths of the drainage ditches are very variable and mostly determined by the width of the tillage tool. The depth of the drainage ditch depends often on the soil depth. The gradient of ditches varied considerably from farmer to farmer from $3 \%$ to $20 \%$ (Million, 1996). Turkelboom et al. (2008) found drainage ditches with gradients of $15-50 \%$. In developing countries, decisions on the dimensions of the ditch construction variables (width, depth, and gradient) are based on indigenous knowledge of local conditions and empirical observations. Although some studies mention dimensions of drainage ditches as discussed earlier, there is a scarcity of literature about the explanatory factors of drainage densities on sloping farmland and about quantities of soil loss associated with the use of drainage ditches.

The main two categories of man-made drainage systems are the following: (i) subsurface drains and (ii) surface drains. Subsurface drainage systems are situated beneath the soil, so the land can be farmed over the drain. Their initial cost is however high (Luthin, 1966). Different surface drainage ditch systems can be distinguished on sloping lands, where they are often ephemeral as they are destroyed during preparatory tillage of the land and shaped again (by hoe or plow) after crop emergence in the period when overland flow starts to occur (Shiferaw, 2002; Million, 1996). The cross-slope ditch system or interception system consists of ditches at the lower end of the slope. Water from the farmland is captured by open collector ditches, running at a slight angle with the contour. The random-ditch system is applied in fields where random depressions exist that 
are too deep to fill by land smoothing. The ditches will connect these depressions to transport the excess of water downslope. Surface-drainage bedding system is an old drainage practice. Beds are formed in the farmland and separated by parallel open field ditches (Luthin, 1966). These ditches are oriented towards the greatest land slope. Typical examples of such land surface drainage techniques are the Camber bed drainage in, for example, Ghana (Nyalemegbe et al., 2010) and Ethiopia (Srivastava et al., 1993) or the broad bed and furrow (Astatke et al., 2002; Morrison et al., 1990) both of which have been promoted with variable degrees of success (Gebreegziabher et al. 2009). A collector drain at the lower end of the field gathers all the drained water. Parallel-ditch system can be used on flat, poorly drained soils. The land between the parallel ditches is smoothed, so the overland flow encounters no obstruction. For all of the aforementioned systems, the cross-sections of the ditches are trapezoidal or V-shaped if they are smaller (Luthin, 1966).

\section{DRAINAGE DITCHES AND DOWNSTREAM HYDROGEOMORPHIC RESPONSES}

The use of drainage ditches has an impact on the farmland itself and on the downstream area (Table I). Drainage ditches may cause hydrogeomorphic changes because of their repetitive and expansive nature (Spaling \& Smit, 1995). For example, drainage is frequently associated with a reduction in wetlands or changes in stream discharge (Figure 1). Those changes can be positive, as already discussed, or negative: the establishment of drainage ditches is increasingly recognized as a major factor of off-site environmental impact, as it increases sediment load and peak runoff rate and thus increasing flooding problems downstream (Skaggs et al., 1994).

\section{Gully Formation}

The erosive force of the concentrated water flow in the drainage ditches may initiate downslope gullying of valley bottoms and further incision of existing waterways (Ireland et al., 1939; Simane et al., 2013). Farmlands with significant surface run-on may suffer from gully development as observed in the highlands of northern Thailand. Human-made linear landscape features such as diversion ditches or footpaths are most important for runoff concentration, rapid transmission of peak flows to the lower part of the catchment, and hence gully development (Turkelboom et al., 2008). Burkard \& Kostachuk (1995) studied gullies in glacial clays in Ontario and observed gully expansion resulting from alteration of surface drainage patterns by agricultural drainage ditches. Archibold et al. (2003) reported similar observations in a catchment in Saskatoon (Canada) where snowmelt is the most prominent source of soil moisture and surface runoff. When the soils are saturated, infiltration capacity is too low, and more water is concentrated into the drainage ditch system, which drains into valley bottoms, gullies, and first-order streams. Lack of cooperation between land users upstream for safe drainage and gully protection may hence lead to severe downstream gully erosion (Smit \& Tefera, 2011). Zhang et al. (2013) and Simane et al. (2013) emphasize the importance of a well-thought drainage ditch design in order to benefit from the positive effects resulting from drainage ditches, while reducing the downstream effects. A poorly planned drainage ditch layout leads to enhanced gully erosion downstream (Simane et al., 2013) and causes higher peak runoff discharge, with concomitant losses of soil and nutrients (Zhang et al., 2013).

\section{Increased Peak Discharges}

The peak discharge in rivers will be larger where hill slopes have a high drainage density. The drainage density comprises both drainage ditches and natural drainage by gully channels (Holden et al., 2004; Skaggs et al., 1994). Turkelboom et al. (2008) found that gully development is closely related to the runoff-generating areas, runoffconcentrating features, and connective elements within the catchment. Drainage ditches increase the runoff connectivity in the catchment (Sidle et al., 2006). The presence of a drainage network is one of the most critical characteristics to identify farmlands that cause off-site problems (Turkelboom et al., 2008). But Trafford (1973) and Thomasson (1975) downplay the effect of drainage ditches on peak discharges: drainage of permeable soils generally results in a lowering of the flow peaks. The concept here is that the drainage ditches lower the temporary water table (induced by seasonal rainfall) and hence increase the temporary storage capacity of the top soil layer (Thomasson, 1975). This results in a larger capacity of the soil to absorb the rain that falls during the beginning of each event.

\section{DRAINAGE DITCHES AND ON-SITE GULLY INITIATION}

\section{Gully Formation}

The concentrated water flow in the surface drainage ditch system may also generate on-site effects on the farmland. There is scarcity of literature on this topic although problems of on-site gully initiation are widespread. In western Washington (USA) (Veldhuisen \& Russel, 1999) and on the steep and wet highlands of northern Thailand (Turkelboom et al., 2008), drainage ditch failures were observed when ditches got clogged by sediment. Runoff could break through the ditch wall, divert the water out of the drainage ditch, and create a rill or a gully. The lack of maintenance of physical structures such as stone bunds (sensu Nyssen et al., 2007) or drainage ditches reduces their effectiveness and even allows concentrated flow that enhances gully development (Tebebu et al., 2010; Shiferaw, 2002). At smallholder level, particularly in complex terrain, creating an effective drainage ditch system requires experience, (indigenous) knowledge of soils, and skills, as too steep ditches enhance incision and gully formation, too shallow ditches create overflow of the ditches and rill 


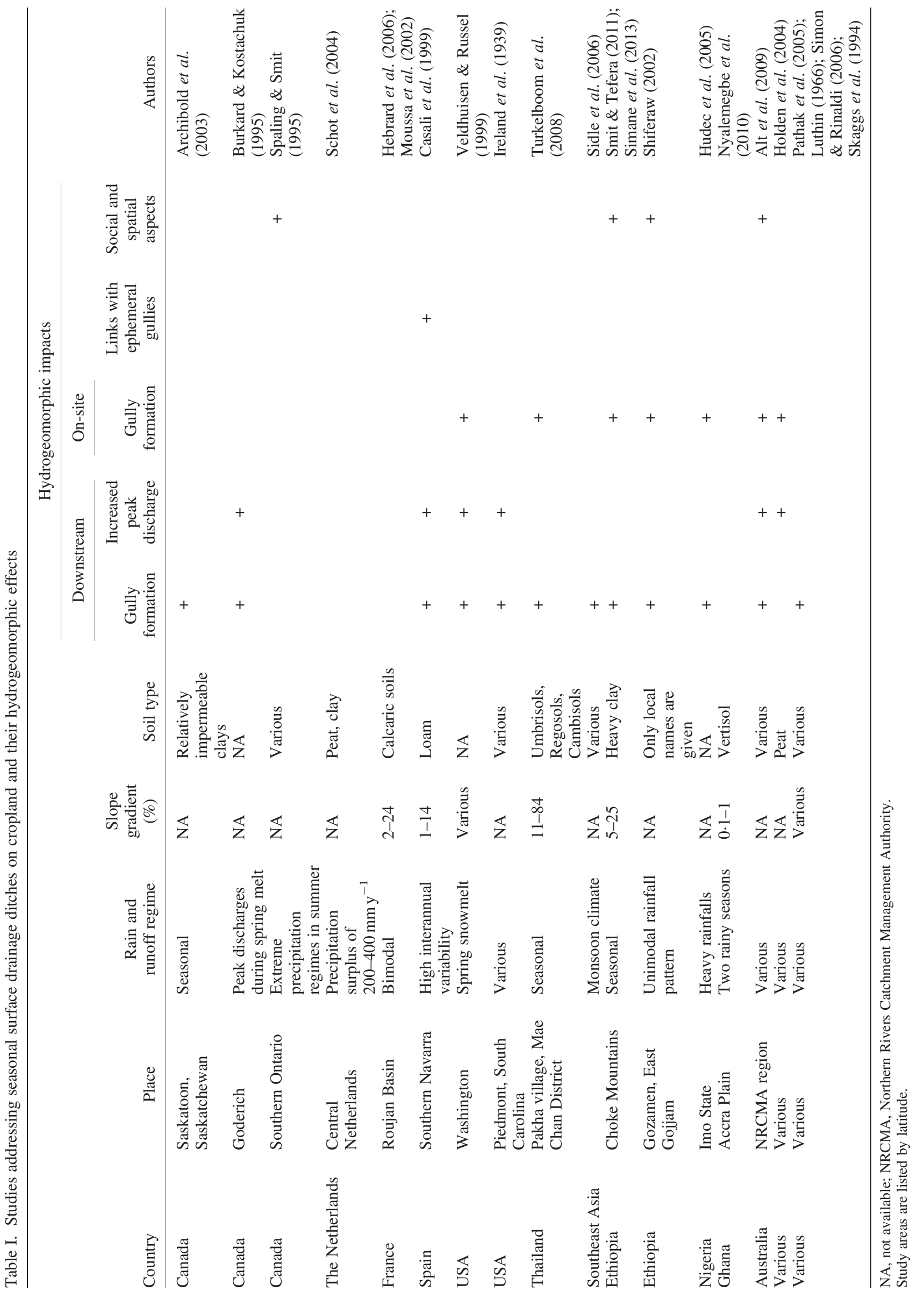




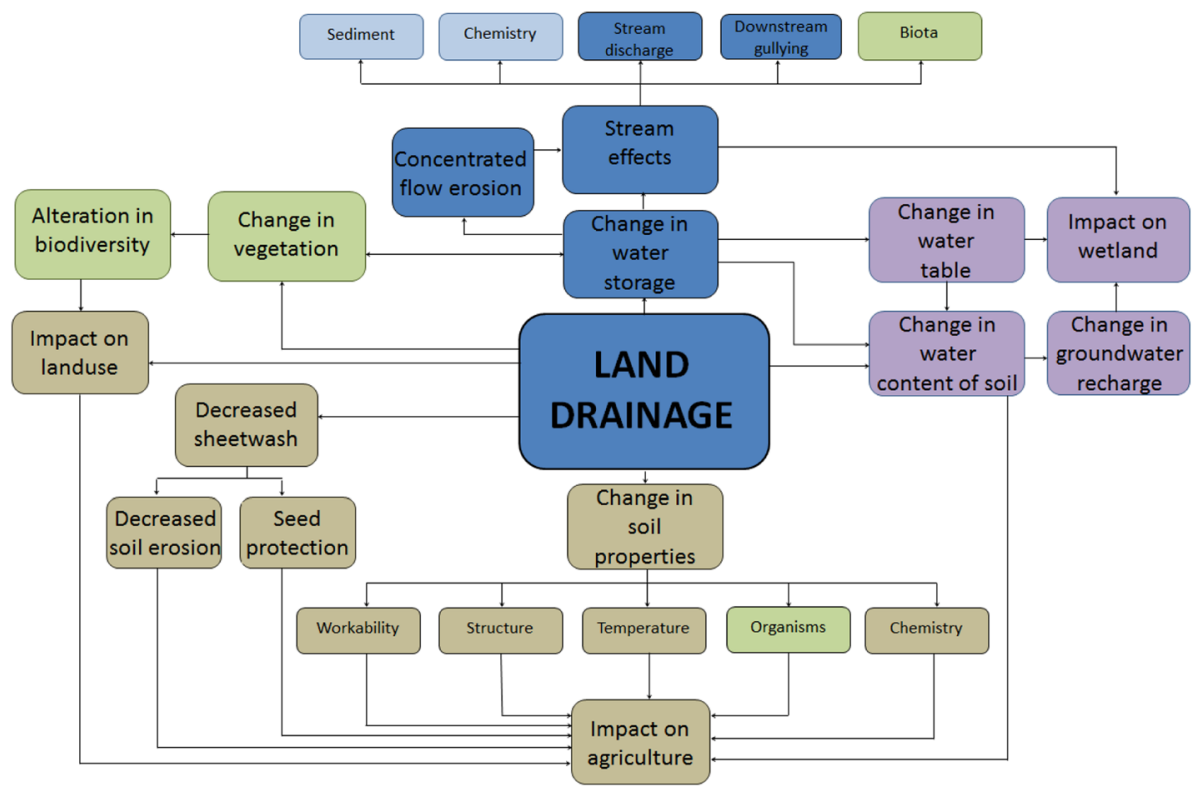

Figure 1. Environmental changes induced by drainage ditch construction: in brown color changes linked to agriculture, in green to vegetation and biodiversity, in purple to groundwater, and in blue to surface water. Changes addressed in this study are in dark blue (modified from Spaling \& Smit, 1995). This figure is available in colour online at wileyonlinelibrary.com/journal/ldr.

formation, and too many ditches are time and space consuming (Smit \& Tefera, 2011). Poor design and obstruction of the drains are major causes of gully initiation (Hudec et al., 2005; Alt et al., 2009; Smit \& Tefera, 2011).

Holden et al. (2004) studied the impact of peat drainage and concluded that wetland soils suffer from severe degradation due to ditches that can quickly erode deeply. Incised drainage ditches allow higher peak flows and are very dynamic, while they dissipate little flow energy (Simon \& Rinaldi, 2006). Ditch degradation and widening over time are the undesirable effects (Alt et al., 2009; Simon \& Rinaldi, 2006) (Figure 2). To avoid ditches developing into gullies, farmers will yearly change their position (Shiferaw, 2002; Million, 1996).

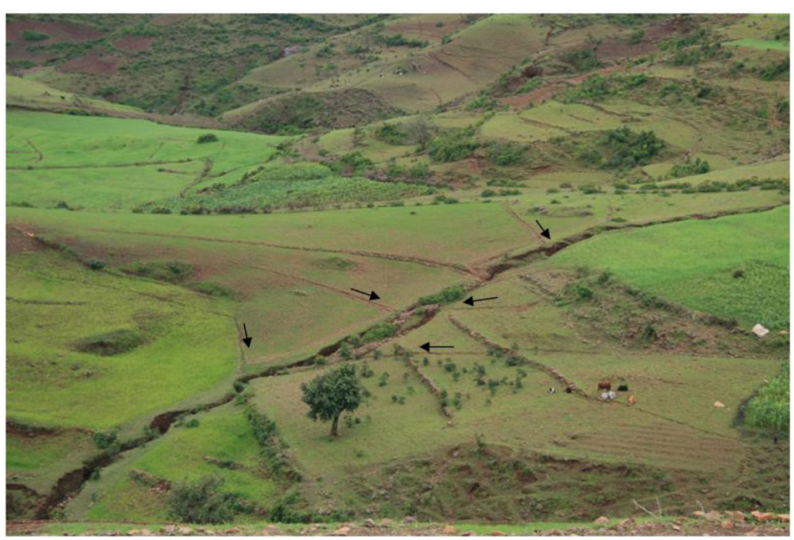

Figure 2. Slightly slanted drainage ditches on cropland drain surface runoff towards a main drainage ditch running downslope (diagonally through the photograph) and hence induce gully erosion. Direction of flow in the drainage ditches is indicated by arrows. Farmers make use of both drainage ditches and stone bunds (Wanzaye, Ethiopia, Aug. 2013). This figure is available in colour online at http://wileyonlinelibrary.com/journal/ldr.
Ireland et al. (1939) characterize gully forms of which some are determined by drainage ditches (Figure 3); particularly, the linear form is common along parcel borders following old or existing drainage ditches, and the parallel system can be formed out of parallel ditches.

\section{Other On-site Effects}

Substantial on-site soil losses to the underground drainage system have also been observed in a catchment in Ullensaker (Norway). This subsurface soil loss was accelerated by the soil saturation at the end of a snowmelt period (Oygarden et al., 1997).

Another possible on-site effect of the construction of drainage ditches is moisture deficit at the end of the rainy season. Hebrard et al. (2006) emphasize the large influence of land management such as drainage ditch networks on soil moisture distribution in a catchment. Nevertheless, literature

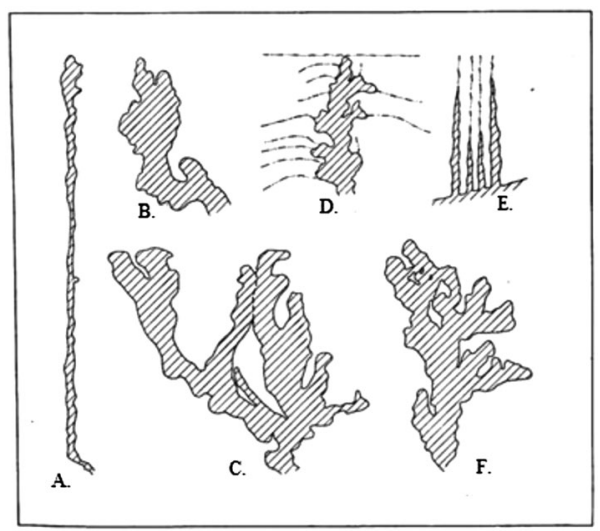

Figure 3. Characteristic gully forms in relation to surface drainage:( A) linear, (B) bulbous, (C) dendritic, (D) trellis, (E) parallel, and (F) compound (after Ireland et al., 1939). 
is very scarce on the specific causal relation between drainage ditches and moisture stress for crops at the end of the rainy season.

\section{INTERACTIONS AND SIMILARITIES BETWEEN DRAINAGE DITCHES AND EPHEMERAL GULLIES}

Besides man-made drainage ditches, also the effects of natural drainage on hydro-geomorphology can be considered. The hydrological processes associated with ditches were also observed with EGs (Poesen \& Hooke, 1997), that is, clearly formed natural waterways mostly reoccurring at the same place (Foster, 1986). Swiechowicz (2011) showed that EGs on cultivated areas in Poland are most frequently formed on cultivated slopes in natural drainage lines. Studies conducted in the Mediterranean area (MartinezCasasnovas et al., 2005), China (Zhang et al., 2007), and in Ethiopia (Bewket \& Sterk, 2003; Tebebu et al., 2010) confirm the findings of EG formation on cultivated land, which constitutes the main drainage system. Casali et al. (1999) studied EG erosion in Spain by which three main types of EGs are distinguished: (i) classical EG, (ii) drainage EG; and (iii) discontinuous EG. The drainage EG was formed by flows from drainage ditches in upstream farmlands that erode the cultivated plots downstream. They found that drainage EG was the most active EG and hence eroded the largest volume of soil. Also, in Ethiopia, we observed that many EGs are fed by runoff water from slanted drainage ditches, although there is a lack of research about this topic. According to Tebebu et al. (2010) and Easton et al. (2010), gullies grow more easily on saturated soils because of positive pore water pressures reducing the shear strength of the soils. Overland flow is the main factor of gully erosion on cropland (Govers et al., 1990; Auzet et al., 1993). Fields in midslope positions are more susceptible for rill erosion because of the runoff concentration (Bewket \& Sterk, 2003).

When EGs are not controlled by tillage operations, they can grow into large gullies (Woodward, 1999; Bennett et al., 2000; Le Roux \& Sumner, 2012). Tillage-induced roughness can redirect runoff water from topographically determined directions of flow to tillage lines. This concentrated flow can initiate uncontrolled EGs (Takken et al., 2001).

Long-term productivity of the farmland declines because of the repeated removal of top soil by gully erosion followed by the filling operations (Poesen et al., 2006; Yitbarak et al., 2012). Another effect of this process is the gradual lowering of the soil surface (Woodward, 1999; Burkard \& Kostachuk, 1995; Valentin et al., 2005). The most documented on-site effects of water erosion and surface runoff include nutrient and soil losses (Poesen \& Hooke, 1997; Steegen et al., 2001; Martinez-Casasnovas et al., 2005). All these effects of EGs are also applicable to ephemeral drainage ditches that are created yearly in farmers' fields in different but nearby and parallel positions.

\section{DRAINAGE AND GULLYING IN RELATION TO SOCIAL AND UPSTREAM-DOWNSTREAM POWER CONFLICTS}

The history of the conflict concerning the effects of manmade hillslope drainage in England has been summarized by Robinson (1990). Severe floods of the Thames (London), Severn (Wales), and other large rivers in England were claimed as being the inevitable result of upstream drainage of farmland. The divided academic opinion about the effects of drainage ditches caused governmental inconstancy. For many years, the government has been giving public money to farmers for construction of drainage ditches, whereas they recognized that further research of the hydrological effect of agricultural drainage is required. The study of Bankoff (2013) indicates that this discussion in England is still of interest today.

Similarly, drainage of peatlands has worldwide been the subject of conflict between different stakeholders such as nature conservationists and economists who want to increase farmland productivity (FAO, 2012; Koivusalo et al., 2008). Wetland loss by peat drainage has severe consequences for local populations in Africa depending on the source of water and nutrients required for biological productivity. However, decision makers often perceive wetlands to have little value compared with drained wetlands with more visible and immediate economic benefits (Schuyt, 2005). Also, in Scotland, the relationship between peatland soils and man-induced drainage has gained attention (Bragg, 2002).

Smit \& Tefera (2011) investigated the reason why gully erosion is still present on a hill slope of the Choke Mountain (Ethiopia) despite more than 20 years of soil conservation programs. They concluded that land degradation is not caused by intensive cultivation but by the absence of a coordinated drainage ditch system that results from the occurring social relations within the community. Larger landowners have a higher status and are put in a favorable position when disputes arise concerning land, irrigation water, or other 'public goods' distribution. This makes them privileged to construct drainage ditches that may benefit their crop yield but are detrimental for their downslope neighbors. Different interests and different social and topographical positions make it hard to establish a cooperation between land users to stop gully formation.

Farmers try to construct their drainage ditches in such way that they will end up in a stream, forest, or a fallow land that can slow down the runoff velocity and trap the transported sediment (Turkelboom et al., 2008). However, Shiferaw (2002) points to the major limitation of drainage ditches in a watershed in East Gojjam (Ethiopia): the ditches are constructed in order to find the best way to drain the excess of water so that they may have to cross croplands belonging to different farmers. These drainage ditches hence form a potential source of conflict between neighboring farmers.

Case studies on drainage ditches (Smit \& Tefera, 2011; Shiferaw, 2002; Turkelboom et al., 2008) confirm the theory of Lanckriet et al. (2014) following Blaikie et al. (1994), 
who state that traditional crop producers in nondeveloped countries are not in a chronic crisis, but the economic impoverishment is caused by human interactions with nature. Despite the land degradation factors often put forward in literature, Lanckriet et al. (2014) emphasize the political mode of production (traditional subsistence, power relations, civil war, and postwar) and its related conservation strategies.

\section{AN ILLUSTRATION IN LAKE TANA BASIN IN ETHIOPIA}

\section{Situation}

The Lake Tana Basin is situated in the northwestern Ethiopian highlands and comprises about 2.5 million people. The basin includes Lake Tana $\left(3041 \mathrm{~km}^{2}\right)$, which is the largest lake in the country and fills a volcano-tectonic depression at $1785 \mathrm{~m}$ asl (Setegn et al., 2010; Poppe et al., 2013). The Lake Tana Basin contains lacustrine deposits and the weathering material of basalts both of which support fertile soils (Colot, 2012), particularly Vertisols and Nitisols, as well as Leptosols on the steeper slopes (Miserez, 2013). More than half of the Lake Tana Basin is used for agriculture (Setegn et al., 2009). The most applied production system in the Lake Tana Basin is the grain-plow complex, with crop production consisting for $70 \%$ of cereals (Westphal, 1975).

\section{Seasonality and Rainfed Farming}

Rainfall in Lake Tana Basin is highly seasonal with more than $70 \%$ of the rainfall occurring in the kremt season (June to September). The rainfall pattern has an important impact on crop cultivation. The growing season for the Lake Tana region is limited to the duration of the rainy season and a subsequent period with residual moisture (Colot, 2012). Rainfed farming agriculture is dominant in the Lake Tana Basin, as it is in most parts of Ethiopia (Colot, 2012; Araya et al., 2012; Hurni et al., 2005).

\section{Traditional Drainage Ditches}

Traditional drainage ditches in humid and subhumid regions of Ethiopia are dug on hillslopes during the rainy season. These ditches are locally known as feses. The reasons farmers give for constructing drainage ditches are the following: (i) to avoid soil erosion by runoff water; (ii) to avoid loss of seeds directly after sowing; and (iii) to drain accumulating water away from their fields. Feses are constructed using the maresha ard plow, drawn by a pair of oxen (Gebreegziabher et al., 2009). The gradient, number, spacing, depth, and width of the ditches on cultivated land can differ from farmer to farmer, from plot to plot, and among crop types. The width of the ditch is chosen by the farmer in function of the depth of the soil, although usually fixed by the width of the ox plow (Shiferaw, 2002).

We studied ten catchments $(0 \cdot 27-4 \cdot 21 \mathrm{ha})$ in the Gumara sub-basin $\left(1279 \mathrm{~km}^{2}\right)$ during the rainy season of 2013 ; only in one catchment no drainage ditches were present. Drainage densities in the other nine catchments ranged from 53 to $510 \mathrm{~m} \mathrm{ha}^{-1}$. The average drainage density by ditches over the nine catchments was $282( \pm 155) \mathrm{m} \mathrm{ha}^{-1}$. Farmers constructed drainage ditches that departed from the contour with angles between $0^{\circ}$ and $90^{\circ}$ with an average of $45^{\circ}$. Interviewed experienced farmers stated that drainage ditches perpendicular to the contour make no sense as they do not catch much runoff; besides, they cause severe land degradation (deepening and widening of the ditch). The top width of all ditches was on average $27( \pm 9) \mathrm{cm}$ (measured directly after establishment), with a minimum of $15 \mathrm{~cm}$ and a maximum of $80 \mathrm{~cm}$. After the crops have reached a certain height (decision varies from farmer to farmer), these feses were filled with weeding materials because the functions of the drainage ditches mentioned earlier were not necessary anymore. A significant correlation was found in the ten catchments between stone bund density and ditch drainage density $(R=-0 \cdot 72)$, whereas the latter is also negatively correlated to soil depth (Table II). The negative correlation between stone bund density and drainage density can be explained by the government policy that forbids making feses where stone bunds were constructed at governmental initiative. In this way, the government tries to avoid land degradation by the use of drainage ditches and hence to support sustainable land management. Nevertheless, drainage ditches still appear in combination with stone bunds (Figure 2) for different reasons mentioned by the farmers: (i) no maintenance of the stone bunds and hence malfunctioning; (ii) the excess of water needs to be drained away; and (iii) water overflowing the stone bunds does erode their field. Local courts are very busy during the rainy season resolving conflicts between farmers concerning feses construction draining water to neighboring farmer's fields. There is only one verdict as the authorities follow the government policy; and hence; the drainage ditch has to be closed.

Table II. Correlation matrix for catchment and drainage density statistics in the Lake Tana Basin

\begin{tabular}{lccccr}
\hline & Ditch drainage density & Stone bund density & Soil depth & Stoniness & Top width of drainage ditches \\
\hline Average slope gradient & 0.37 & -0.17 & $-0.64^{*}$ & $0.68^{*}$ & $0 \cdot 14$ \\
Ditch drainage density & & $-0.72 *$ & -0.40 & 0.08 & $0 \cdot 25$ \\
Stone bund density & & & -0.04 & 0.26 & 0.32 \\
Soil depth & & & $-0.79^{*}$ & -0.31 \\
Stoniness & & & & $0 \cdot 19$ \\
\hline
\end{tabular}

*Correlation at a $0 \cdot 05$ significance level. 


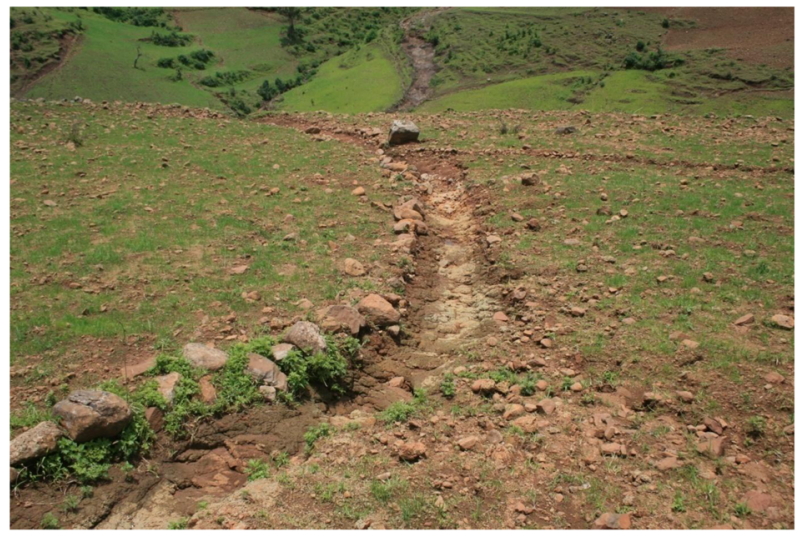

Figure 4. Bedrock exposure by gully erosion due to the construction of a feses drainage ditch construction in cropland near Wanzaye, Ethiopia (August 2013). In the background, another gully has cut the soil down to the bedrock. This figure is available in colour online at http://wileyonlinelibrary. com/journal/ldr.

\section{Soil Erosion Related to Drainage Ditches}

Farmers alternate the position of the traditional constructed ditches every cropping season in order to avoid their gradual widening and deepening over time (Shiferaw, 2002). Farmers are aware of the fact that drainage ditches transport fertile topsoil from their land downstream. But according to the farmers in Lake Tana Basin, feses are the best way to avoid soil erosion in the beginning of the rainy season if no other on-site conservation measures like stone bunds are available. As a result of this soil transport, the bottom of the feses frequently reaches down to the bedrock (Figure 4).

Rill erosion and gully formation are the most important processes causing soil loss by water that form a severe threat to the subsistence rainfed agriculture and the national economy of Ethiopia. Thus, the lack of knowledge of the following: (i) the process of gully erosion (Poesen et al., 2003; Tebebu et al., 2010) and (ii) the environmental impacts of artificial drainage (Skaggs et al., 1994), is problematic as it can lead to mismanagement in the basin. This concerns also the livelihoods of tens of millions of people downstream in the lower Nile River Basin.

\section{CONCLUSIONS}

Sloping farmland is susceptible to erosion induced by high rainfall, seasonal soil saturation, and the construction of drainage ditches. Man-made soil drainage has a range of benefits for the farmer's land, although researchers are still divided about the balance of their positive and negative effects. The similarities and interactions between EGs and drainage ditches have to be considered to account for all effects of drainage. The use of drainage ditches has both on-site and off-site impacts. Downstream problems such as increased sediment load, higher peak discharges, and gully initiation are well documented. Gully erosion appears as a result of the combination of runoff-generating areas (saturated soils), runoff-concentrating features (drainage ditches), and connectivity in the catchment. But few studies deal with the on-site effects of drainage ditches, although problems of soil removal and gully initiation are reported. We recommend further research about the on-site effects of drainage ditches on root depth, moisture conditions, and rill and gully formation. The case of the Lake Tana Basin illustrates the importance to further study the following: (i) the hydrogeomorphic impacts of drainage ditches and (ii) the similarities with the processes of EG erosion. This will enhance better management strategies to reduce the negative impacts on the environment. Finally, drainage ditches are a potential source of conflict between neighboring farmers with different interests and power positions.

\section{ACKNOWLEDGEMENTS}

We thank the assistance of the WaSe-Tana project, a cooperation between Ghent, Leuven, and Bahir Dar Universities, funded by the Belgian development cooperation through VLIR-UOS. We also thank the VLIR-UOS in funding this research through a travel scholarship for E. M. Field discussions with farmers around Wanzaye (Ethiopia) contributed to sharpen our insights in the matter. Constructive comments by Artemi Cerdà and Paolo Billi on an earlier version of this paper are gratefully acknowledged.

\section{REFERENCES}

Alt S, Jenkins A, Lines KR. 2009. Saving soil-a landholder's guide to preventing and repairing soil erosion. NSW Department of Primary Industry: New South Wales.

Araya T, Cornelis WM, Nyssen J, Govaerts B, Getnet F, Bauer H, Amare K, Raes D, Haile M, Deckers J. 2012. Medium-term effects of conservation agriculture based cropping systems for sustainable soil and water management and crop productivity in the Ethiopian Highlands. Field Crops Research 132: 53-62. DOI: 10.1016/j.fcr.2011.12.009

Archibold OW, Levesque LMJ, de Boer DH, Aitken AE, Delanoy L. 2003. Gully retreat in a semi-urban catchment in Saskatoon, Saskatchewan. Applied Geography 23: 261-279. DOI: 10.1016/j.apgeog.2003.08.005

Astatke A, Jabar M, Mohamed-Saleem MA, Erkossa T. 2002. Development and testing of low cost animal drawn minimum tillage implements: experience on Vertisols in Ethiopia. Agricultural Mechanization in Asia, Africa, and Latin America 33: 9-14

Auzet AV, Boiffin J, Papy F, Ludwig B, Maucorp J. 1993. Rill erosion as a function of the characteristics of cultivated catchments in the north of France. Catena 20: 41-62. DOI: 10.1016/0341-8162(93)90028-N

Bankoff G. 2013. The 'English Lowlands' and the North Sea Basin system: a history of shared risk. Environment and History 19: 3-37. DOI: 10.3197/096734013X13528328438992

Bayabil HK, Tilahun SA, Collick AS, Yitaferu B, Steenhuis TS. 2010. Are runoff processes ecologically or topographically driven in the (sub) humid Ethiopian highlands? The case of the Maybar watershed. Ecohydrology 3: 457-466. DOI: 10.1002/eco.170

Bennett SJ, Casali J, Robinson KM, Kadavy KC. 2000. Characteristics of actively eroding ephemeral gullies in an experimental channel. Transactions of the ASAE 43: 641-649. DOI: 10.13031/2013.2745

Bewket W, Sterk G. 2003. Assessment of soil erosion in cultivated fields using a survey methodology for rills in the Chemoga watershed. Agriculture, Ecosystems \& Environment 97: 81-93. DOI: 10.1016/S0167-8809 (03)00127-0

Blaikie P, Brookfield HC, Allen B. 1994. Land degradation and society. Routledge: London.

Bragg OM. 2002. Hydrology of peat-forming wetlands in Scotland. Science of the Total Environment 194: 111-129. DOI: 10.1016/S00489697(02)00059-1 
Burkard MB, Kostachuk RA. 1995. Initiation and evolution of gullies along the shoreline of Lake Huron. Geomorphology 14: 211-219. DOI: $10.1016 / 0169-555 X(95) 00059-\mathrm{E}$

Casali J, Lopez JJ, Giraldez JV. 1999. Ephemeral gully erosion in southern Navarra (Spain). Catena 36: 65-84. DOI: 10.1016/S0341-8162(99)00013-2

Colot C. 2012. Soil-landscape relation at regional scale in Lake Tana Basin (Ethiopia). Unpublished MSc thesis. KU Leuven: Department of Earth and Enviornmental Sciences.

Easton ZM, Fuka DR, White ED, Collick AS, Ashagre BB, McCartney M, Awulachew SB, Ahmed AA, Steenhuis TS. 2010. A multi basin SWAT model analysis of runoff and sedimentation in the Blue Nile, Ethiopia. Hydrology and Earth System Sciences 14: 1827-1841. DOI: 10.5194/ hess-14-1827-2010

FAO. 2012. Peatlands. Guidance for climate change mitigation through conservation, rehabilitation and sustainable use. Mitigation of Climate Change in Agriculture Programme. Food and Agriculture Organization of the United Nations, Rome (114 pages).

Foster GR. 1986. Understanding ephemeral gully erosion. In Soil conservation: an assessment of the national resources inventory, Vol. 2. The National Academies Press: Washington, DC; 90-125.

Gebreegziabher T, Nyssen J, Govaerts B, Getnet F, Behailu M, Haile M, Deckers J. 2009. Contour furrows for in situ soil and water conservation, Tigray, Northern Ethiopia. Soil \& Tillage Research 103: 257-264. DOI: 10.1016/j.still.2008.05.021

Govers G, Everaert W, Poesen J, Rauws G, De Ploey J, Lautridou JP. 1990. A long flume study of the dynamic factors affecting the resistance of a loamy soil to concentrated flow erosion. Earth Surface Processes and Landforms 15: 313-328. DOI: 10.1002/esp.3290150403

Haile GW, Fetene M. 2012. Assessment of soil erosion hazard in Kilie catchment, East Shoa, Ethiopia. Land Degradation \& Development 23: 193-306. DOI: 10.1002/ldr.1082

Hebrard O, Voltz M, Andrieux P, Moussa, R. 2006. Spatio-temporal distribution of soil surface moisture in a heterogeneously farmed Mediterranean catchment. Journal of Hydrology 329: 110-121. DOI 10.1016/j.jhydrol.2006.02.012

Holden J, Chapman PJ, Labadz JC. 2004. Artificial drainage of peatlands: hydrological and hydrochemical process and wetland restoration. Progress in Physical Geography 28: 95-123. DOI: 10.1191/ 0309133304pp403ra

Hudec PP, Simpson F, Akpokodje EG, Umenweke MO. 2005. Anthropogenic contribution to gully initiation and propagation in southeastern Nigeria. Reviews in Engineering Geology 16: 149-158. DOI: 10.1130/ 2005.4016(13)

Hurni H, Tato K, Zeleke G. 2005. The implications of changes in population, land use, and land management for surface runoff in the upper Nile Basin area of Ethiopia. Mountain Research and Development 25: 147-154. DOI: 10.1659/0276-4741(2005)025[0147:TIOCIP]2.0.CO;2

Ireland HA, Sharpe CFS, Eargle DH. 1939. Principles of gully erosion in the Piedmont of South Carolina. U.S. Department of Agriculture:

James AL, Roulet NT. 2009. Antecedent moisture conditions and catchment morphology as controls on spatial patterns of runoff generation in small forest catchments. Journal of Hydrology 377: 351-366. DOI: 10.1016/j.jhydrol.2009.08.039

Koivusalo H, Ahti E, Lauren A, Kokkonen T, Karvonen T, Nevalainen R, Finer L. 2008. Impacts of ditch cleaning on hydrological processes in a drained peatland forest. Hydrology and Earth System Sciences 12: 1211-1227. DOI: 10.5194/hess-12-1211-2008

Lanckriet S, Derudder B, Naudts J, Araya T, Cornelis W, Bauer H, Deckers J, Haile M, Nyssen J. 2014. Politics of land degradation under different land policies in the North Ethiopian Highlands. Land Degradation and Development DOI: 10.1002/ldr.2278.

Le Roux JJ, Sumner PD. 2012. Factors controlling gully development: comparing continuous and discontinuous gullies. Land Degradation and Development 23: 440-449. DOI: 10.1002/ldr.1083

Luthin JN. 1966. Drainage engineering. Wiley: New York.

Martinez-Casasnovas JA, Ramos MC, Ribes-Dasi M. 2005. On-site effects of concentrated flow erosion in vineyard fields: some economic implications. Catena 60: 129-146. DOI: 10.1016/j.catena.2004.11.006

Mekuria A, Vlek PLG, Denich M. 2012. Application of the caesium-137 technique to soil degradation studies in the Southwestern Highlands of Ethiopia. Land Degradation \& Development 23: 456-464. DOI: 10.1002/ldr.1088

Million A. 1996. Traditional ditches in northern Shewa, Ethiopian Highlands. In Sustaining the soil: indigenous soil and water conservation in Africa, Reij C, Scoones I, Toulmin C (eds). IIED: London, UK; 163-169.
Miserez A. 2013. Soil erodibility and mapping in different hydrological land systems of Lake Tana Basin, Ethiopia. MSc thesis, KU Leuven.

Morrison JE, Gerik TJ, Chichester FW, Martin JR, Chandler JM. 1990. A no-tillage farming system for clay soils. Journal of Production Agriculture 3: 219-227.

Moussa R, Voltz M, Andrieux P. 2002. Effects of the spatial organization of agricultural management on the hydrological behaviour of a farmed catchment during flood events. Hydrological Processes 16: 393-412. DOI: $10.1002 /$ hyp.333

Ngatcha BN, Ekodeck GE, Mpele M, Ntana PE. 2011. Hydrological and geotechnical investigations of mass movements in an equatorial city (Yaounde, Cameroon). Environmental Earth Sciences 62: 1733-1747. DOI: $10.1007 / \mathrm{s} 12665-010-0654-8$

Nyalemegbe KK, Darkwa EO, Yangyuoru M, Mawunya FD, Acquah DK, Oteng JW, Terry PJ, Willcocks TJ. 2010. The effect of camber bed drainage landforms on soil nutrient distribution and grain yield of maize on the Vertisols of the Accra Plains of Ghana. West African Journal of Applied Ecology 16: 1-8.

Nyssen J, Poesen J, Gebremichael D, Vancampenhou K, D'aes M, Yihdego G, Govers G, Leirs H, Moeyersons J, Naudts J, Haregeweyn N, Haile M, Deckers J, 2007. Interdisciplinary on-site evaluation of stone bunds to control soil erosion on cropland in Northern Ethiopia. Soil and Tillage Research 94: 151-163.

Oygarden L, Kvaerner J, Jenssen PD. 1997. Soil erosion via preferential flow to drainage systems in clay soils. Geoderma 76: 65-86. DOI: 10.1016/S0016-7061(96)00099-7

Pathak P, Wani SP, Sudi R. 2005. Gully control in SAT watersheds. Global theme on agroecosystems Report no 15. Patancheru 502 324, Andhara Pradesh, India: International Crops Research Institute for the Semi-Arid Tropics.

Poesen J, Hooke JM. 1997. Erosion, flooding and channel management in the Mediterranean environments of southern Europe. Progress in Physical Geography 21: 157-199.

Poesen J, Nachtergaele J, Verstraeten G, Valentin C. 2003. Gully erosion and environmental change: importance and research needs. Catena 50: 91-133. DOI: 10.1016/S0341-8162(02)00143-1

Poesen J, Vanwalleghem T, de Vente J, Knapen A, Verstraeten G, Martínez-Casasnovas JA. 2006. Gully erosion in Europe. In Soil erosion in Europe, Boardman J, Poesen J (eds). John Wiley \& Sons: Ltd, Chichester, UK. DOI: 10.1002/0470859202.ch39

Poppe L, Frankl A, Poesen J, Admasu T, Dessie M, Adgo E, Deckers J, Nyssen J. 2013. Geomorphological map of the Lake Tana Basin (Ethiopia). Journal of Maps 9(3): 431-437.

Qureshi AS, Ahmad W, Ahmad AA. 2013. Optimum groundwater table depth and irrigation schedules for controlling soil salinity in central Iraq Irrigation and Drainage 62: 414-424. DOI: 10.1002/ird.1746

Robinson M. 1990. Impact of improved land drainage on river flows, Institute of Hydrology, Rep. No. 113. Crowmarsh Gifford, Wallingford, Oxon, U.K.

Schot PP, Dekker SC, Poot A. 2004. The dynamic form of rainwater lenses in drained fens. Journal of Hydrology 293: 74-84. DOI: $10.1016 / \mathrm{j}$ hydrol.2001.01.009

Schuyt KD. 2005. Economic consequences of wetland degradation for local populations in Africa. Ecological Economics 53: 177-190. DOI: 10.1016/j.ecolecon.2004.08.003

Setegn SG, Srinivasan R, Dargahi B, Melesse AM. 2009. Spatial delineation of soil erosion vulnerability in the Lake Tana Basin, Ethiopia. Hydrological Processes 23: 3738-3750. DOI: 10.1002/hyp.7476

Setegn SG, Srinivasan R, Melesse AM, Dargahi B. 2010. SWAT model application and prediction uncertainty analysis in the Lake Tana Basin, Ethiopia. Hydrologycal Processes 24: 357-367. DOI: 10.1002/hyp.7457

Shiferaw M. 2002. Linking indigenous with 'Conventional' measures for substainable land management in the highlands of Ethiopia: a case study of Digil watershed, East Gojjam. Unpublished thesis. Addis Ababa University: College of Social Sciences.

Sidle RC, Ziegler AD, Negishi JN, Nik AR, Siew R, Turkelboom F. 2006 Erosion processes in steep terrain-truths, myths, and uncertainties related to forest management in Southeast Asia. Forest Ecology and Management 224: 199-225. DOI: 10.1016/j.foreco.2005.12.019

Simane B, Zaitchik BF, Ozdogan M. 2013. Agroecosystem analysis of the Choke Mountain Watersheds, Ethiopia. Sustainability 5: 592-616. DOI: $10.3390 /$ su5020592

Simon A, Rinaldi M. 2006. Disturbance, stream incision, and channel evolution: the roles of excess transport capacity and boundary materials in controlling channel response. Geomorphology 79: 361-383. DOI: 10.1016/j.geomorph.2006.06.037 
Singh S, Agnihotri SP. 1987. Rill and gully erosion in the subhumid tropical riverine environment of Teonthar Tahsil, Madhya Pradesh, India. Geografiska Annaler Series A: Physical Geography 69: 227-236. DOI: $10.2307 / 521380$

Skaggs RW, Brevé MA, Gilliam JW. 1994. Hydrologic and water quality impacts of agricultural drainage. Critical Reviews in Environmental Science and Technology 24: 1-32.

Smit H, Tefera G. 2011. Understanding land degradation on a hill slope of the Choke Mountains in Ethiopia. Conference paper -Building resilience to Climate Change in the Blue Nile highlands, Addis Ababa, Ethiopia.

Spaling H, Smit B. 1995. A conceptual model of cumulative environmental effects of agricultural land drainage. Agricultural Ecosystems \& Environment 35: 99-108. DOI: 10.1016/0167-8809(94)00566-W

Srivastava KL, Abiye A, Tekalign M, Hailu R, Selamyihun K. 1993. Land, soil and water management. In Improved management of Vertisols for sustainable crop-livestock production in the Ethiopian highlands: synthesis report 1986-92, Tekalign M, Abiye A, Srivastava KL, Asgelil $\mathrm{D}$ (eds). Technical committee of the joint Vertisol project: Addis Ababa, Ethiopia; 75-84

Steegen A, Govers G, Takken I, Nachtergaele J, Poesen J, Merckx R. 2001. Factors controlling sediment and phosphorus export from two Belgian agricultural catchments. Journal of Environmental Quality 30: $1249-1258$

Steenhuis TS, Collick AS, Easton ZM, Leggesse ES, Bayabil HK, White ED, Awulachew SB, Adgo E, Ahmed AA. 2009. Predicting discharge and sediment for the Abay (Blue Nile) with a simple model. Hydrological Processes 23: 3728-3737. DOI: 10.1002/hyp.7513

Swiechowicz J. 2011. The development of ephemeral gullies in cultivated areas of Wisnicz Foothills, Poland. Landform Analysis 17: 209-214.

Takken I, Govers G, Steegen A, Nachtergaele J, Guérif J. 2001. The prediction of runoff flow directions on tilled fields. Journal of Hydrology 248: 1-13. DOI: 10.1016/S0022-1694(01)00360-2

Tebebu TY, Abiy AZ, Dahlke HE, Easton ZM, Zegeye AD, Tilahun SA, Collick AS, Kidnau S, Moges S, Dadgari F, Steenhuis TS. 2010. Surface and subsurface flow effect on permanent gully formation and upland erosion near Lake Tana in the Northern Highlands of Ethiopia. Hydrology and Earth System Sciences 7: 5235-5265. DOI: 10.5194/hess-14-2207-2010
Thomasson AJ. 1975. Hydrological and environmental aspects. In Soils and field drainage. Technical monograph no. 7, Thomasson AJ. (Ed.). Soil Survey of England and Wales: Harpenden; 62-65.

Tilahun SA, Guzman CD, Zegeye AD, Engda TA, Collick AS, Rimmer A, Steenhuis TS. 2013. An efficient semi-distributed hillslope erosion model for the subhumid Ethiopian Highlands. Hydrology and Earth System Sciences 17: 1051-1063. DOI: 10.5194/hess-17-1051-2013

Trafford BD. 1973. The relationship between field drainage and arterial drainage-theoretical aspects. FDEU Technical Bulletin 73-10.

Turkelboom F, Poesen J, Trebuil G. 2008. The multiple land degradation effects caused by land-use intensification in tropical steeplands: a catchment study from northern Thailand. Catena 75: 102-116. DOI: 10.1016/j.catena.2008.04.012

Valentin C, Poesen J, Li Y. 2005. Gull erosion: impacts, factors and control. Catena 63: 132-153. DOI: 10.1016/j.catena.2005.06.001

Veldhuisen C, Russel P. 1999. Forest road drainage and erosion initiation in four west-cascade watersheds. TFW Effectiveness Monitoring Report. Timber/Fish/Wildlife monitoring advisory group and the northwest Indian fisheries commission. http://www.dnr.wa.gov/Publications/ fp_tfw_mag1_99_001.pdf (accessed on 1.11.2013)

Westphal E. 1975. Agricultural systems in Ethiopia. Centre for Agricultural Publishing and Documentation: Wageningen.

Woodward DE. 1999. Method to predict cropland ephemeral gully erosion. Catena 37: 393-399. DOI: 10.1016/S0341-8162(99)00028-4

Yitbarak TW, Belliethathan S, Stringer LC. 2012. The onsite cost of gully erosion and cost-benefit of gully rehabilitation: a case study in Ethiopia. Land Degradation \& Development 23: 157-166. DOI: 10.1002/ldr.1065

Zhang YG, Wu YQ, Lin BY, Zheng QH, Yin JY. 2007. Characteristics and factors controlling the development of ephemeral gullies in cultivated catchments of black soil region, Northeast China. Soil \& Tillage Research 96: 28-41. DOI: 10.1016/j.still.2007.02.010

Zhang ZY, Kong LL, Zhu L, Mwiya RM. 2013. Effect of drainage ditch layout on nitrogen loss by runoff from an agricultural watershed. Pedosphere 23: 256-264.

Ziadat FM, Taimeh AY. 2013, Effects of rainfall intensity, slope, land use and antecedent moisture on soil erosion in arid environment. Land Degradation \& Development 24: 582-590. DOI: 10.1002/ldr.2239 